\title{
Research on the Ideal and Belief Education of Young Students in the New Era
}

\author{
Yang Zhongying ${ }^{1}$, Yan Jianke, * \\ ${ }^{1}$ Business School, Central University of Finance and Economics, Beijing, China \\ ${ }^{2}$ Asset Management Division, Capital University of Economics and Business, Beijing, China
}

Email address:

itdarkblue@163.com (Yan Jianke)

*Corresponding author

\section{To cite this article:}

Yang Zhongying, Yan Jianke. Research on the Ideal and Belief Education of Young Students in the New Era. Higher Education Research. Vol. 6, No. 2, 2021, pp. 40-46. doi: 10.11648/j.her.20210602.12

Received: March 22, 2021; Accepted: April 6, 2021; Published: April 16, 2021

\begin{abstract}
In the new era, the cultivation of young students' thoughts and values is facing new problems. The goal of this paper is to explore how to better carry out the ideal and belief education of young students in the new era, and constantly improve the effectiveness of ideological and political education in colleges and universities. ideal and belief are the concentrated embodiment of individual world outlook, outlook on life and values, which play an important role in guiding and supporting the direction of the cultivation of outstanding moral character of young students and the sustainable development and prosperity of the nation. Ideal and belief education is the core content of ideological and political education for young students, and it is an inevitable choice for colleges and universities to train builders and successors of socialist cause. This paper analyzes the scientific definition and significance of ideal and belief, expounds the characteristics of the ideal and belief education for young students in the new era, and then discusses how to promote the ideal and belief education for young students in the new era from four dimensions: strengthening scientific theory education, deepening the education of party history and national conditions, expanding social practice education and enriching effective educational carriers.
\end{abstract}

Keywords: New Era, Young Students, Ideal and Belief Education

\section{Introduction}

In times of change, young people are often the vanguard; in social progress, young people must be the main force. Young students are the new force in society, and their youth is in the golden and critical period of life, with high enthusiasm and strong plasticity. Socialism with Chinese characteristics has entered a new era, which is not only a new historical orientation of China's development, but also the development background of our society for a long time in the future. In the new era, the political and economic situation at home and abroad is complex and changeable, the rapid development of network information technology brings more unstable factors, the struggle in the ideological field is more complex and hidden, and the rapid development of higher education itself brings many new contradictions. The changes of these new social factors make the young students' ideas and value orientation appear diversified and complex new characteristics. The ideological and political education for young students is facing new situation, new contradiction and new challenge. Therefore, focusing on the fundamental task of moral education, grasping the key to education of ideal and belief, and cultivating newcomers of the era who are worthy of the task, are the urgent tasks of ideological and political education in colleges and universities. ideal and belief, as a unique spiritual phenomenon of human beings, restrict people's value orientation and behavioral choices, and are a concentrated expression of individual worldview, outlook on life and values. ideal and belief play an important role in cultivating the outstanding moral character of young students and in the sustainable development and prosperity of the country and nation.

This paper hopes to take the ideal and belief education as an important starting point to improve the ideological and political education of young students in the new era. This paper expounds the scientific definition and significance of ideal and belief, analyzes the characteristics of the times of ideal and belief education, and provides effective suggestions 
on how to carry out the ideal and belief education of young students in the new era, so as to effectively promote the effectiveness of moral education in Colleges and universities, and cultivate talents for the country in the new era.

\section{The Scientific Definition and Significance of Ideal and Belief}

\subsection{The Scientific Definition of Ideal and Belief}

Ideal is imaginable possibilities linked to the goals of struggle, which are formed in practice, possible to achieve, and pursuit for future society and self-development. Ideal is a multi-level and complex system of value goals, in which the value pursuit of social ideals, that is, the leading value of a better future society that people expect to achieve, is the basic standard of all value judgments, and has a dominant position for the value pursuit of other forms of ideal.

Belief is a mental state established by the subject on the basis of certain cognition, which firmly believes in certain thoughts and ideals and practices them. In social practice, when people are convinced of a certain idea or theoretical point of view and put it into practice, it means that people have formed a certain belief. Russell believes that belief is composed of an idea or image plus an emotion that feels right [1]. What he said "feeling right" is the subject's belief in an object, which is the key to the formation of belief. Only when the subject believes, can faith be established. Faith is not only inner belief, but also behavior and practice. It is the guarantee of belief to persevere in a certain object of belief.

In the historical tradition of the party's ideological and political education, ideal and belief refer to Marxist scientific beliefs and firm socialist ideal and belief. Mao Zedong pointed out: "Our future program or maximum program is to advance China into a socialist society and a communist society. This is definite and beyond doubt. [2]" Deng Xiaoping pointed out: "We have struggled for many years for communism, and our belief and ideal is to engage in communism. [3]" Xi Jinping emphasized: "The belief in Marxism and communism, and the belief in socialism are the spiritual 'calcium' of the communists. Without ideal and belief, if ideal and belief are not firm, they will suffer from rickets mentally and shake around in front of the wind and rain. [4]" The ideal and belief in the party's ideological and political education discourse system are the social ideal and belief at the highest level as ideal and belief. The ideal and belief of socialism and communism are the concentrated manifestations of the self-consciousness formed by the proletariat and communists through the practice and deep thinking of the law of human social development and their own historical missions. They are the loftiest ideals in human history so far. The fundamental goal of ideal and belief education for young students is to guide students to gradually form and recognize the common ideal of socialism with Chinese characteristics in their study and life, and then establish a firm belief in lifelong struggle for the cause of communism.

\subsection{The Significance of Ideal and Belief}

Ideal and belief education is the core content of ideological and political education for young students. The mainstream thinking of contemporary young students is positive. They love the party, the motherland and socialism. However, some young students have some problems in varying degrees, such as confused political beliefs, vague ideal and belief, distorted value orientation, and even some students have erroneous tendencies such as "material-based beliefs", "device-based beliefs" and "God-based beliefs". According to the new situation and characteristics of young students' ideal and belief in the new era, we should further clarify the core position of ideal and belief education in young students' ideological and political education and strengthen the organic combination of young students' social ideals and personal ideals, so as to help young students form a correct world outlook, outlook on life and values, and guide them to establish a firm belief in unremitting struggle for the great rejuvenation of the Chinese nation.

Ideal and belief education is an inexhaustible driving force that leads young students to grow and become talents. Moral education to cultivate people is the fundamental task of education in the new era. To implement this fundamental task in an all-round way is to realize the free and comprehensive development of people. The fundamental reason why the ideal and belief education of young students can become an inexhaustible driving force for the development of college students is that it has the basic attributes of spiritual motivation and behavioral thrust. "The majority of young people must strengthen their ideals and convictions. The merits are only for the purpose, and the career is broad for the diligence. Ideals guide the direction of life, and beliefs determine the success or failure of careers. Without ideal and belief, it will lead to mental calcium deficiency. [5]" As a goal orientation, ideals guide people's direction; as a kind of spiritual power, ideals encourage people to explore and pursue continuously. The core content of ideal and belief education for young students is social ideals, that is, political beliefs and moral beliefs. This is to guide young students to pursue a sound political system and noble moral sentiments to ensure political governance and promote social development. In the new era, advocating the promotion and integration of social ideals and personal ideals in the ideal and belief education of young students is an effective driving force for young students to realize social value in their own development.

Ideal and belief education is an inevitable choice for training builders and successors. What kind of people to train is the primary issue of education. Xi Jinping emphasized: "My country's higher education shoulders the important task of cultivating socialist builders and successors with comprehensive development of moral, intellectual, physical, and aesthetic. It must adhere to the correct political direction. The foundation of higher education lies in the establishment of morality and the cultivation of people. [6]" Qualified builders include training young students to become knowledgeable and morally qualified high-quality talents. While reliable 
successors include cultivating young students to become useful talents who firmly believe in Marxism and communism ideal and belief, support the leadership of the Communist Party of China and our country's socialist system, and are determined to fight for socialism with Chinese characteristics throughout their lives. Ideal and belief education mainly undertakes the task of cultivating young students into reliable successors. It is necessary to fully integrate the education of ideal and belief into all aspects of the cultivation of young students, and to achieve an effective connection with the central task of the party and the country's ideological construction.

\section{The Characteristics of Ideal and Belief Education of Young Students in the New Era}

\subsection{Ideological Penetration in the Context of Multiculturalism Is More Covert and Intense}

$\mathrm{Xi}$ Jinping has repeatedly stressed the importance of ideological work. "The disintegration of a regime often starts from the ideological field, political turbulence and regime change may occur overnight, but the ideological evolution is a long-term process. The ideological line is broken, and it is difficult for other lines to hold. We must fully understand the extreme importance of ideological work, firmly grasp the leadership, management and discourse power of ideological work, and cannot be left behind at any time, otherwise we will make irreparable historical mistakes. [7]" In the new era, western countries use various covert ways to infiltrate our ideology.

The spread of wrong thoughts confuses young students' correct vision of ideal and belief. The main erroneous thoughts present-day society are neoliberalism, democratic socialism, nationalism, historical nihilism, cultural conservatism, universal value, postmodernism and individualism. Among them, the outstanding performance of historical nihilism in the new period is to slander the Chinese people's struggle against imperialism and feudalism for national independence and people's liberation, and to negate China's socialist orientation and its great achievements. Even with regard to the source of the new crown pneumonia epidemic, western countries, dominated by the United States, have tried to stigmatize China and confuse the people of the world. "The western capitalist countries rely on their strong economic strength and adopt the methods of" ideology of economic problems "and" economy of ideological problems "to carry out infiltration. [8]" At the same time, they use the powerful form of cultural industry to publicize the so-called "universal value" in a vain attempt to control of the youth of our country.

The more subtle way of ideological infiltration is trying to dispel the ideal and belief of socialism-communism. Western developed countries have resorted to modern communication technology and under the banner of fair competition, trying to impact my country's local culture and mainstream market through dialogue and cultural exchanges, strengthen ideological penetration, and even distort socialist values. The ideology of young students is not perfect. Facing the impact of hidden culture, they cannot be effectively identified, and their ideal and belief tend to show instability. With the rapid spread of the Internet, popular culture can provide support for the ideal and belief education of colleges and universities, but it also allows more hidden capitalist thoughts and ideologies to enter and spread, eroding and corrupting the values and ideal and belief of some young students.

\subsection{The Leap in International Status Has Set a New Benchmark for the Education of Young Students' Ideal and Belief}

The 19th National Congress of the Communist Party of China solemnly declares that socialism with Chinese characteristics has entered a new era, which means that the Chinese nation and people have ushered in a new era of strengthening and that Chinese youth are standing at a new historical starting point. With the rapid growth of economic strength, China's soft power in politics, society and culture is steadily rising, and its international influence is increasing day by day. The stereotype that China is poor and weak, closed and conservative, and the system lacks vitality is gradually broken. China is increasingly approaching the center of the world stage. China's international status and influence determine China's dream, which is not only related to China's fate, but also to the fate of the world. Xi Jinping said at the celebration of the 40th anniversary of reform and opening up: "We must play the role of a responsible big country, support the development of developing countries, actively participate in the reform and construction of the global governance system, and work together to build lasting peace, universal security, common prosperity, openness and tolerance. Strive for a clean and beautiful world. [9]" As a strong and unyielding nation, the Chinese nation has created a miracle of development in modern world history, further stimulated the patriotic enthusiasm of young students in the new era, and strengthened their ideal and belief in realizing the Chinese dream of great rejuvenation of the Chinese nation.

The new crown pneumonia epidemic that began in 2020 has swept the world and constituted an unprecedentedly complex social crisis. China's outstanding performance and amazing achievements in this epidemic have once again proved to the world the unparalleled advantages of the socialist system with Chinese characteristics, set a Chinese benchmark for mankind's prevention and control of major epidemics, and contributed to China's experience and Chinese solutions. In this great struggle, countless Chinese youths defy hardships, charge ahead, and forget their lives, demonstrating the vigorous power of youth. This war epidemic not only tested the youth of the new era, but also greatly inspired the patriotic enthusiasm of Chinese young students and their strong confidence in the motherland. It also made young students more aware of their mission and responsibilities. Young people in the new era are born at the right time and have important responsibilities on their shoulders. Faced with the 
unprecedented changes in the past century, contemporary youth should set up lofty ideal and belief, and have a lofty ambition and down-to-earth temperament of the times.

\subsection{The Growth of Young Students in the New Era Presents New Changes and New Characteristics}

Young students' ideal and belief are realistic and secularized. The value standard of equivalent exchange in the market economy profoundly affects people's thinking and behavior. Under the temptation of various social interests, some young students began to focus on personal interests, while ignoring collective interests. The most obvious manifestation is the blurring of the personal and social ideals of some young people. Without paying attention to the country's major policies and social hotspots, and lacking in-depth thinking about the status quo and problems of society, there is no way to build social ideals. At the same time, some young people's personal ideal utilitarianism is prominent.

Young students' ideal and belief are diversified and complicated. Engels pointed out: "The theoretical thinking of every era, including our own, is a product of history. It has completely different forms and completely different contents in different times. [10]" The ideal and belief of contemporary Chinese youth refer to Marxist scientific beliefs and firm socialist ideal and belief. However, with the influx of western social thoughts, the ideal and belief of young students appear complex and diverse forms, which brings great impact to the ideal and belief of young students who are in the formation of values. For example, western humanism makes young students pay more attention to self-selection and self-value realization when establishing ideal and belief.

The ideal and belief of young students are emotional and contradictory. The diversification and complexity of ideal and belief will inevitably lead to the weakening of ideal and belief, and bring about psychological and behavioral irrelevance to young students, so that their ideal and belief present perceptual and contradictory characteristics. Because young students' own life and social experience are still in a relatively inadequate state, they lack basic understanding of social phenomena and political issues, but they often have strong idealism and personal emotions, making it difficult for them to touch the essence of political issues. At the same time, young students often show a clear perceptual color in their value choices, causing their ideal and belief to deviate from their real life, and then showing individuality and universal contradiction.

The ideal and belief of young students are impacted by the negative information of new network media. In the new era of Internet and we media, mass culture is spreading rapidly in various forms. Young students are keen on and even rely on the Internet, but they are lack of effective value judgment of new things, and are easy to be induced by the decadent culture in the new media. In addition, the current mode of ideal and belief education in China is relatively backward, which is still dominated by indoctrination and enlightenment, so the effectiveness of ideal and belief education has been greatly challenged.

\section{Exploration on the Methods of Ideal and Belief Education for Young Students in the New Era}

\subsection{To Strengthen the Education of Ideal and Belief, We \\ Must Continue to Strengthen the Education of Scientific Theories}

Without theoretical maturity, there can be no political firmness. Only when we truly have a higher quality of Marxist theory can we firmly grasp the general trend of world development and strengthen the socialist direction and communist ideal [11]. Only by being proud of the achievements our nation has made in the pursuit of the highest ideals can we strengthen our determination and confidence in the ideal and belief we are pursuing. Just like Lenin's evaluation of the source of Marxism: "The whole genius of Marx lies in that he answered all kinds of questions that have been put forward by advanced human thoughts, and the emergence of his theory is the direct continuation of the theories of philosophy, political economy and the great representatives of socialism. [12]" The three major sources of Marxism, the ultimate reason for their sublimation to Marxism, are Marx's in-depth investigation of the times and the world, and his profound grasp of the laws governing the development of human society, based on his solid and profound study of Western philosophy, political economy and utopian socialism. True knowledge can produce true faith, and true faith can produce the motive force of dreaming, so that young students can March forward bravely towards ideal and belief. Young students' belief in socialism is a developing process from sensibility to rationality. Only in the rational stage can we make a judgment that socialism is first of all a kind of "science" and not just a kind of "doctrine" that people believe in, and we can truly believe it and stand the test of all kinds of wrong thoughts and bad temptations.

To carry out scientific theory education is to strengthen the systematic education of young students' Marxism-Leninism, Mao Zedong Thought, and the theory of socialism with Chinese characteristics. Ideological and political theory courses in colleges and universities are the main channel of ideological and political education for college students. It is necessary to vigorously promote the introduction of scientific theories and important ideas into teaching materials, classrooms, and college students' brain work, so as to achieve true learning, true understanding, true belief, and true use, which will help to lay a solid foundation for college students' ideal and belief. Curriculum ideology and politics is to realize that all kinds of professional courses and ideological and political theory courses are in the same direction in the form of constructing a whole staff, whole process and whole curriculum education pattern. It needs to strengthen the practical development education of various theoretical disciplines in China, extract Chinese stories, and analyze Chinese cases. It should introduce the successful experience of various scientific theories in China to young students, and form a synergistic effect with the ideological and political 
theory courses, and jointly practice the fundamental educational task of "cultivating morality and cultivating people".

\subsection{To Strengthen the Education of Ideal and Belief, We Must Continue to Deepen the Education of Party History and National Conditions}

As early as when working in Zhejiang, Xi Jinping pointed out at the provincial conference on strengthening and improving ideological and political education for college students that it is necessary to "carry out in-depth education on the party's basic theory, basic line, basic program and basic experience, carry out education on the history of Chinese revolution, construction and reform, carry out education on basic national conditions, provincial conditions and situation policies, and carry out education on the scientific development concept, so that college students can establish common ideals and firm beliefs. [13]" Only by studying and deeply understanding the history of our country and nation from ancient times to the present, and taking history as a mirror, can we know the rise and fall and face the future scientifically; Only by knowing the historical development and great practice of socialism with Chinese characteristics and the historical inevitability of socialism with Chinese characteristics can we strengthen our firm belief in striving for the lofty ideal of communism and the common ideal of socialism with Chinese characteristics for life.

To carry out party history and national conditions education, one of which is to educate young people on party history, which is to make young students clarify the party's history. It is necessary to emphasize that young students learn the history of the party, especially the history of the party, the history of the new China, the history of reform and opening up, and the history of socialist development, inherit the fine traditions of the party, and focus on educating young people from a historical perspective; The education of policies and lines enables young people to understand the current undertakings of the party and the country, so as to gather young people into the great cause of national rejuvenation from both horizontal and vertical dimensions.

The second is to educate the youth about the national conditions, which is to strengthen the confidence of the youth in the cause of the party and the people. It is necessary to educate young people to understand that our country is in a new era of socialism with Chinese characteristics, from standing up to getting rich and strong. Young students must strengthen their confidence in the leadership of the party and in the development of the country and the nation. At the same time, let young people understand more that our country is in a new historical position, and that new great victories require young people to shoulder more social responsibilities. It is necessary to attach importance to the current party's basic line, principles and policies, as well as domestic and foreign situations and policy education, and continuously enhance the practical awareness and responsibility of young students.

Third, it is necessary to guide students to think more, compare more, and have a correct understanding of Chinese characteristics and international comparisons. It is necessary for young students to have a comprehensive and objective understanding of contemporary China, look at the outside world, recognize the objective laws of social development and the inevitable trend of historical development, and recognize the positive and negative experiences and lessons of socialist construction. Help young students to correctly understand the responsibilities of the times and historical missions, understand the future and destiny of the country and their own social responsibilities, build their ideal and belief on the basis of science, integrate their personal ideals into the development and progress of the country and the nation, and move forward courageously.

\subsection{To Strengthen the Education of Ideal and Belief, We Should Continue to Expand the Education of Social Practice}

Practice is the only standard to test the truth, and it is also the realistic source of young students' ideal and belief. Mao Zedong pointed out: "the reason why Marx, Engels, Lenin and Stalin were able to make their theories, in addition to their talent conditions, was that they personally participated in the class struggle and the practice of scientific experiments at that time. [14]" Learning is the ladder of growth and progress, practice is the way to improve ability and realize belief, and the great ideal of young Marx and Engels to liberate all mankind is gradually formed and firm in the practice of fighting against the bourgeoisie. Xi Jinping emphasized: "Do solid work and be a solid person. Tao can't be sat down, virtue can't be empty talk. If you persevere, success will be waiting for you ahead. [15]"

Schools should increase the practical study of young students in school. The main task of young students in school is to receive classroom education, so whether it is ideological and political education, or professional teaching, we should follow the practical principle, and try to design the links and requirements of practical education and teaching. In the daily ideological and political education work, we should constantly enrich the content and depth of voluntary activities, social practice in winter and summer vacation, employment practice and other main practice carriers, and encourage young students to participate in the practice of major events such as the Winter Olympic Games. Let the young students go through the storm, see the world, grow their skills and increase their talents in the specific investigation and observation and work operation, so that they can more closely understand and understand the actual situation of Chinese society, distinguish right from wrong. And it will finally help the students go to the society, bear social responsibility, and constantly refine their ideal and belief.

\subsection{To Strengthen the Education of Ideal and Belief, We Must Continue to Enrich Effective Education Carriers}

It is necessary to pay more attention to educating people through culture, extensively carry out the establishment of civilized campuses, and carry out campus cultural activities in 
various forms, healthy and progressive, and elegant in style. Campus culture is an important carrier to improve the education of ideal and belief for young people. It is an effective hidden educational resource that can unknowingly affect the ideology, values and behavior of young students. Therefore, while carrying out the education of ideal and belief, colleges and universities should pay attention to the construction of campus culture, and organically integrate the education of ideal and belief with the construction of campus culture to help students form scientific ideal and belief and correct values. It is necessary to actively give play to the cultivating function of various party and league organizations, and promote party organizations, labor unions, Communist Youth League, student unions, student clubs and other groups to play their educational and leading functions, so as to better represent teachers and students, unite teachers and students, and serve teachers and students. Through the condensing and spreading of school motto, school song, and school spirit, young students can feel the arduous journey of their ancestors in starting a business, and cultivate the spiritual qualities of being grateful and chasing after the sages. The school should actively organize outstanding student appraisal activities, encourage young students to accumulate more scientific knowledge, form a good ideological and moral cultivation, so as to better form correct ideal and belief. It is necessary to fully explore the educational connotation of the red culture, organize visits to old revolutionary areas, conduct social surveys and other activities to enable young students to form a deeper understanding of the Chinese Communist Party and the party's history, and establish a strong sense of social responsibility and mission.

We should use new media and new technology to promote the high integration of traditional advantages of ideological and political work with information technology, and enhance the sense of the times and attractiveness of our work. "The Internet is a big platform for social information, on which hundreds of millions of Internet users obtain and exchange information, which will have an important impact on their way of seeking knowledge, way of thinking and values, especially on their views on the country, society, work and life. [16]" The growth of contemporary youth is accompanied by the development of network technology. The network can affect the values of young students to a great extent, and even disintegrate the correct ideological system that young students have formed. But from another point of view, the emergence of the network does make up for the shortcomings of the traditional ideal and belief education, and provides more opportunities for open communication between teachers and students. Therefore, educators should accurately grasp the ideological changes of young students with the help of network technology, understand the needs of young students, so as to make the content of ideal and belief education more targeted. Xi Jinping believed that in order to form Internet thinking, we should intensify propaganda on the Internet, use the network to promote social integrity, stimulate positive energy, guide young students to form socialist core values, and give full play to the positive role of network public opinion guidance. Colleges and universities can build red websites and red columns to introduce the great history of New China and the Communist Party of China and the frontier research of the theory of socialism with Chinese characteristics, consolidate the theoretical foundation of students, and let young students have a deeper understanding of the development and achievements of Chinese Society. Colleges and universities can create micro-blog and micro-channel platforms on ideal and belief, regularly push news of activities and publicity reports on deeds of advanced figures, carry out model education, and play a leading role in demonstration.

\section{Conclusion}

What kind of people to cultivate is the primary issue of education. $\mathrm{Xi}$ Jinping pointed out that our party's determination to win the great cause of the Chinese nation must cultivate a useful generation of talented people who support the leadership of the Communist Party of China and China's socialist system and strive for the cause of socialism with Chinese characteristics for a lifetime. The premise of firm support is firm ideal and belief. Therefore, the education of ideal and belief is the core content of cultivating promising young people with lofty morality, outstanding talent, strong responsibility and noble feelings in the new era. Only those with firm ideals and convictions can unswervingly and persevere, be brave of all kinds of difficulties and dangers, and unswervingly strive for the realization of the set goals, so as to shoulder the historical responsibility of strengthening the country and enriching the people. Ideal and belief education cannot be empty slogans, and must be realistic and pragmatic, in order to have a strong appeal, to guide young students to march forward, and to contribute to the new journey of building a socialist modern country in an all-round way.

\section{References}

[1] Russell. (1983). Human knowledge. Beijing: Commercial Press, 183.

[2] Mao Zedong. (1991). Selected works of Mao Zedong. (2nd Edition) [M]. Beijing: People's publishing house, 3: 1059.

[3] Deng Xiaoping. (1993). Selected works of Deng Xiaoping [M]. Beijing: People's publishing house, 3: 137.

[4] Xi Jinping. Speech at the 110th Anniversary Symposium to commemorate the birth of Comrade Chen Yun. Xinhuanet.com, 2015-6-12

http://www.xinhuanet.com//politics/2015-06/12/c 1115603689.htm.

[5] Xi Jinping talks with outstanding youth representatives from all

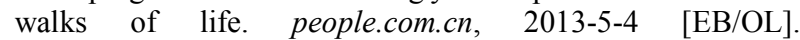
http://cpc.people.com.cn/n/2013/0504/c64094-21365949.html.

[6] Xi Jinping stressed at the National Conference on Ideological and political work in Colleges and Universities: through ideological and political work throughout the whole process of education and teaching, create a new prospect for the development of higher education in China [N]. People's daily, 2016-12-09. 
[7] General secretary Xi Jinping's ruling idea. people.com.cn, 2014-3-3

[EB/OL] http://theory.people.com.cn/n1/2017/0801/c40531-29442583.h tml.

[8] Hou Huiqin. (2010). Marxist Criticism of Ideology and Contemporary China [M]. China Social Sciences Press. 474.

[9] Xi Jinping. (2018). Speech at the celebration of the 40th anniversary of reform and opening up [M]. People's Publishing House, 30-31.

[10] The Compilation Bureau of Works of Marx, Engels, Lenin and Stalin of the Central Committee of the Communist Party of China. (2009). Collected Works of Marx and Engels: Volume Nine [M]. Beijing: People's Publishing House, 436.

[11] Huang Rongsheng. (2004). Ideological and political education of college students: ideal and belief are the core [J]. Ideological and political education in colleges and universities, (12): 10.
[12] Central Bureau of translation and Translation. (2009). Lenin's Monographs on Marxism [M]. Beijing: People's publishing house, 66-67.

[13] Xi Jinping. (2006). Work in practice, walk in the forefront-Thinking and practice of promoting the new development of Zhejiang [M]. Beijing: Party School Press of the CPC Central Committee, 305.

[14] Mao Zedong. (1991). Selected works of Mao Zedong. (2nd Edition) [M]. Beijing: People's publishing house, 1: 287.

[15] Xi Jinping. (2014). Xi Jinping on governing the country [M]. Beijing: foreign languages press, 173-174.

[16] Xi Jinping. Speech at the Symposium on Cyber Security and Informatization [N]. People's Daily, 2016-4-26. 